
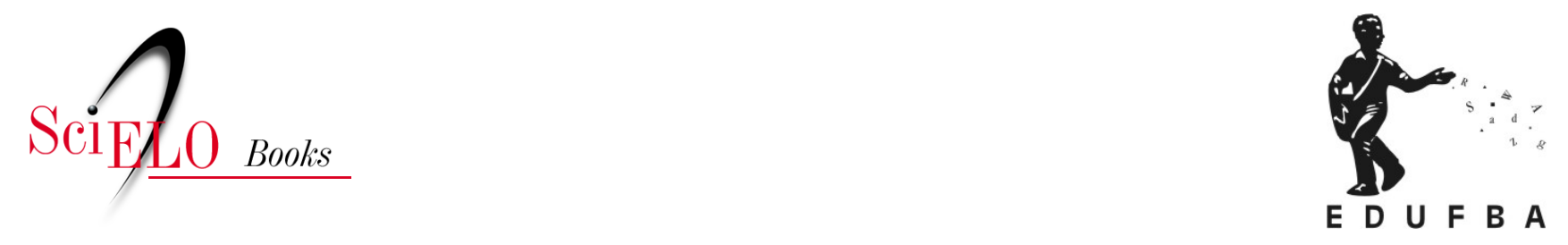

\title{
Humor \\ se você precisa perguntar o que é, então nunca vai saber
}

\author{
Alba Valeria Tinoco Alves Silva
}

\section{SciELO Books / SciELO Livros / SciELO Libros}

SILVA, A.V.T.A. Humor: se você precisa perguntar o que é, então nunca vai saber. In: Deus e o diabo no humor das mulheres: contos, casos e crônicas com humor escritos por mulheres [online]. Salvador: EDUFBA, 2015, pp. 19-47. ISBN: 978-85-232-1868-3.

https://doi.org/10.7476/9788523218683.0003.

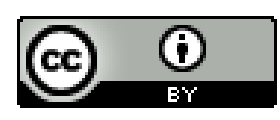

All the contents of this work, except where otherwise noted, is licensed under a Creative Commons Attribution $\underline{4.0 \text { International license. }}$

Todo o conteúdo deste trabalho, exceto quando houver ressalva, é publicado sob a licença Creative Commons Atribição 4.0. 


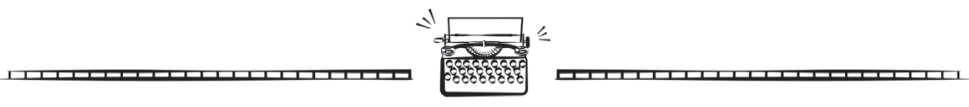

\section{Humor: se você precisa perguntar o que é, entăo nunca vai saber}

"Eu tinha pensado, ao começar esse trabalho, que eu bem que podia definir o que o humor significa para mim. o problema é que cada vez que eu tentava, eu tinha que me deitar um pouco com uma bolsa de gelo na testa." 32

Há uma piada inglesa cuja história se passa num cinema onde estão assistindo a um filme uma velhinha e o seu cão de estimação. Quando a sessão acaba, um homem se aproxima da senhora e diz: "Queira desculpar a intromissão, mas é que eu estou espantado. O seu cachorro parecia não apenas estar entendendo, mas também gostando do filme". Ao que ela responde: "Espantada agora estou eu, ele detestou o livro!".

O homem, provavelmente, quer uma resposta que ponha as coisas no seu devido lugar, que o tranquilize e o faça dizer: "Ufa, que alívio! Por um instante eu pensei que esse cachorro fosse capaz de entender um filme!". Vem a velhinha e chuta a bola para o imponderável. Tentar responder a pergunta "o que é humor?" equivale a 
tentar pegar essa bola. Como se pode observar nesta afirmação de Mário da Silva Brito ${ }^{33}$ :

[...] o humor é diverso da ironia, difere do espírito, mantém respeitável distância da chalaça, opõe-se à sátira, não se confunde com sarcasmo, discrepa do picaresco, diverge do chiste e da verve, aparta-se da farsa e do grotesco, rejeita o gracioso, e, para dar um fim neste emaranhado de distinções, pode aparentar-se ao cômico, se bem que, nem sempre persiga o riso, e, muitas vezes, mesmo ao fazê-lo, ultrapasse esse objetivo e alcance a lágrima, quando não vai beirar e até invadir o trágico, hora em que se torna frequentemente lancinante.

Admite-se que, para que o humor mantenha a sua "aura" de agente irreverente, subversivo, desestabilizador, é interessante que ele não se deixe apreender tão facilmente em taxonomias. Mas, por outro lado, percebe-se também que parece haver entre os estudiosos do tema um certo deleite em fazer da palavra uma espécie de quimera terminológica. Sendo assim, tendo em vista o que é mais produtivo para o escopo deste trabalho, propõe-se que, em vez de achar que o humor não é nada disso, deva-se considerar que o campo do humor ${ }^{34}$ compreende tudo isso: a comédia, a sátira, o chiste, a ironia, o cômico, o besteirol e, como consequência, o riso.

Dito de outra forma, tudo o que não se quer aqui é tentar explicar o que o humor é mas talvez tentar mostrar para que é que ele serve. Para isso, escolheram-se, entre os inúmeros trabalhos sobre o tema, principalmente aqueles que positivam o humor como uma forma interessante de ver o mundo, a começar pelos clássicos.

Na concepção aristotélica de tragédia, um personagem nobre e de caráter nem bom nem mau e, como tal, propenso à simpatia, ao violar uma regra moral ou religiosa, provoca piedade por seu destino e terror pelo seu castigo, que poderia atingir qualquer um dos espectadores do seu drama, de modo que a sua punição significa não

33 BRITO, [197-?], p. 11.

34 Cf. POSSENTI, 2010. 
só a libertação de seu pecado, mas também a purificação das tentações de quem o assiste. Já na comédia, tem-se a violação de uma regra cometida por um personagem inferior, portador de um defeito moral ou físico insignificante e inofensivo, em relação a quem se experimenta um sentimento de superioridade, de modo que a plateia não se identifica nem se comove, mas ri de sua queda, visto que o resultado não será fatal ${ }^{35}$.

Das considerações de Umberto Eco a partir de Aristóteles, podem ser depreendidos três elementos, o sentimento de superioridade em relação ao riso e ao risível, a percepção da violação de uma regra - em termos de desmedida, incongruência, aproximação de opostos, quebra de expectativa etc - e os afetos - a catarse - da plateia em relação ao destino da personagem, em torno dos quais este capítulo será construído.

\section{A superioridade}

A noção de distanciamento ou de superioridade perpassa muitas das principais teorias do riso desde a Antiguidade Clássica, com $O$ Filebo de Platão ${ }^{36}$, até o século XX, com O riso, de Henri Bergson ${ }^{37}$. Mas com distinções fundamentais que aqui serão formuladas e relativizadas a partir das considerações de Verena Alberti em $O$ riso e o risível na história do pensamento ${ }^{38}$.

O primeiro registro de uma teoria sobre o riso encontra-se no Filebo, em que, através do diálogo entre Sócrates e Protarco, Platão condena o riso e o risível. O riso, porque aquele que ri dos males dos próprios amigos, ao invés de se entristecer, comete injustiça

35 ECO, U. O cômico e a regra. In: ECO, U. Viagem na irrealidade cotidiana. 3. ed. Rio de Janeiro: Nova Fronteira, 1984. p. 343-353.

36 PLATÃO. Filebo. Portal Domínio Público, [20--]. Disponível em: < http://www.dominiopublico.gov.br/download/texto/cv000033.pdf > . Acesso em: 26 abr. 2007.

37 BERGSON, H. O riso. Tradução de Ivone Castilho Benedetti. São Paulo: Martins Fontes, 2001.

38 ALBERTI, V. O riso e o risível na história do pensamento. Rio de Janeiro: J. Zahar: Ed. FGV, 1999. 
e experimenta um prazer que tem como causa a inveja. O risível, por ser um vício que infringe a recomendação do oráculo de Delfos: "conhece-te a ti mesmo". Os que ignoram seu conselho se iludem quanto à fortuna, ao corpo e às qualidades da alma, ao crer que são, respectivamente, mais ricos, mais belos e mais virtuosos do que o são na realidade. A maior parte das pessoas que se desconhecem peca por esta última ignorância e, entre as virtudes, é justamente a sabedoria que a maioria tem a pretensão de possuir ${ }^{39}$. Platão ratifica sua visão negativa do riso no livro III de A República, quando diz não ser admissível que se representem homens dignos de consideração sob a ação do riso, o que seria ainda pior quando se representam deuses ${ }^{40}$.

Dentro do conceito platônico, a ordem do divino pertence ao ideal, ao imutável, ao único, ao universal, ao eterno, logo não poderia, como o mundo sensível, ser afetada por uma emoção grosseira capaz de desfigurá-la ou de levá-la à perda do controle e da unidade.

Alberti ${ }^{41}$ ressalta a distância que se verifica entre a concepção aristotélica e aquela que sobressai do Filebo e da República. Por conceber a filosofia como prazer puro e forma única de apreensão da verdade, em oposição à ilusão característica das paixões, Platão possui uma visão negativa do riso e do risível por serem prazeres falsos, experimentados pela multidão medíocre de homens privados da razão. Em Aristóteles, porém, a comédia e o cômico não se relacionam de antemão a valores negativos, como o desconhecimento de si e a inveja, que opõem o prazer cômico ao prazer verdadeiro do conhecimento. Apesar de representar as ações de homens inferiores ${ }^{42}$, no sentido de que não são deuses, sem semideuses, nem membros da realeza, mas homens comuns, isso não implica uma inferioridade a priori da comédia, que, em termos de criação poética, é tão legítima quanto a tragédia.

39 PLATÃO, [20--], p. 37-40.

40 PLATÃO. A República. São Paulo: Nova Cultural, 2000.p.78-79.

41 ALBERTI,1999. p.44-48.

42 FRYE, N. Anatomia da crítica. São Paulo: Cultrix, 1973. p. 39-56. 
Pode-se atribuir positividade à comédia a partir de Aristóteles, na comparação que ele faz entre poesia e história. Ele diz que cabe ao poeta dizer não o que aconteceu de fato, mas o que poderia ter acontecido na ordem do verossímil ou do necessário, já o historiador diz o que aconteceu e se prende ao indivíduo particular e a suas ações. Por partir do geral e prender-se ao tipo de coisa que um certo tipo de homem faz por liame de necessidade e verossimilhança; por referir-se, por essa razão, ao universal, a poesia seria algo mais filosófico e mais sério do que a história. Ele ainda diz que, enquanto os poetas trágicos se atêm aos nomes já existentes, os comediógrafos constroem sua história segundo a verossimilhança e atribuem aos personagens nomes tomados ao acaso, tornando a comédia uma evidência do caráter geral da poesia. ${ }^{43}$

Uma possibilidade de leitura que as considerações de Aristóteles ${ }^{44}$ sugerem é a de que, sendo mais geral e nomeando seus personagens ao acaso e não com base na tradição, talvez a comédia seja mais representativa dos dramas do homem comum do que a tragédia.

Desenvolvendo a noção aristotélica de que a comédia representa as ações de homens inferiores, Northrop Frye ${ }^{45}$ diz que as ficções literárias, no que tange ao enredo, são trágicas quando nelas o herói se isola de sua sociedade e cômicas quando ele se incorpora à sua sociedade. Cada uma das vertentes pode, por sua vez, ser classificada, não moralmente, mas pela força ou ação do herói, que pode ser maior, menor ou igual a nossa. Tal classificação associada ao modo de ficção cômica poderia ser assim articulada: se o herói é superior aos outros homens tanto em condição quanto ao meio, ele é um ser divino, e sua estória é um mito. Se o herói é superior aos outros homens em grau e meio, trata-se do herói da estória romanesca, suas ações são maravilhosas, mas ele é um ser humano. Aqui, o mito propriamente dito passa à lenda, ao conto popular.

43 ARISTÓTELES. Poética. São Paulo: Abril Cultural, 1973. p. 451.

44 ARISTÓTELES, 1973.

45 FRYE, 1973. p.39-56. 
Se superior em grau aos outros homens, mas não a seu meio natural, o herói é um líder. Seu poder é maior do que aquele dos outros homens, mas o que ele faz se sujeita tanto à crítica social como à ordem da natureza. Esse é o herói do modo imitativo elevado, da maior parte da epopeia e da tragédia, e seria o tipo de herói que Aristóteles tinha em mente. O melhor exemplo da comédia imitativa elevada seria a Comédia Antiga de Aristófanes.

Em pé de igualdade com os outros homens e seu meio, o herói é um de nós: sujeito às leis da existência da humanidade comum. Isso equivale ao herói do modo imitativo baixo, da maior parte da comédia e da ficção realística. A Comédia Nova de Menandro seria o exemplo mais próximo do imitativo baixo. Se inferior em poder ou inteligência ao homem comum, de modo que se tem a sensação de olhar de cima uma cena de escravidão, malogro ou absurdez, o herói pertence ao modo irônico.

Frye $^{46}$ observa, também, que, desde Aristóteles, ao longo de 15 séculos, do ponto de vista do receptor de narrativas e dramas, teria havido uma descida da ficção ocidental, no sentido de uma degradação do poder do herói, desde os feitos hercúleos de semideuses até as risíveis desventuras de pobres-diabos entregues ao acaso e à desdita, sem "nada a fazer".

A observação de Frye vem ao encontro da leitura que se fez de Aristóteles de que, mais do que a tragédia, é a comédia o que nos cabe. Leitura que se julga corroborada pela opinião de Millôr Fernandes ${ }^{47}$ :

O livro Todo homem é a minha caça, nome inspirado num poema do inglês Pope, mostra minha profunda descrença no ser humano - que eu sou... [...] Heróis nunca me iludiram. Quando caço o homem, [...], e procuro alvejar individualmente o mesquinho, o covarde, o safado, o hipócrita, o corrupto, o incompetente e, coletivamente, a medicina, a política, a psicanálise, o jornalismo, o economismo, com suas pretensões, falhas, fraquezas, egoísmos e sandices [...] não estou

46 FRYE, 1973, p. 39-56.

47 FERNANDES, M. Millôr definitivo: a bíblia do caos. Porto Alegre: L\&PM, 2002. (L\&PM Pocket, v. 262). 
preocupado com essas falhas e defeitos insanáveis, mas com o inevitável fim a que isso leva - a desumanidade do homem para com o homem [...]. Mesmo o mais humilde, o 'sacerdote' mais 'santo', a sua vanglória o arrasta, pelo menos, a querer ser "o mais humilde do ano". Estão aí Dom Hélder e Madre Teresa de Calcutá que não me deixam mentir. [...] Humorismo é a visão cética no seu mais profundo sentido. Redentora. Aquela que nos permite, honestamente, variar sobre a imagem cansada e repetir: 'O homem está nu!' [...]. Só o ceticismo integral pode começar a produzir um mínimo de verdade, criar um sentimento de maior aproximação com o outro ser humano assim mesmo como ele é [...]. Não adianta nada toda a minha racionalização, não adianta eu olhar no olho de todo e qualquer interlocutor e saber que cada palavra dele - um imenso código sempre mais complicado - não corresponde a nada do que ele é. O sentido de humor, que me faz ver sempre falho - porque a mim não me vejo de outro modo - me mostra toda a complexidade das relações humanas como uma coisa extraordinariamente engraçada, mesmo quando dramática, mesmo quando odiosa, mesmo quando mesquinha. Pois fora do ser humano a vida não tem enredo. Fora do ser humano não há salvação. Não resisto a um ser humano.

Do que foi visto da relação entre riso e superioridade até este ponto, pode-se resumir que, em Aristóteles, o riso é decorrente da imitação das ações do homem inferior. Já em Platão, a superioridade é própria do homem que evita a paixão do riso, concepção que, de certa forma, permanecerá vigente, até a Idade Média.

Segundo Jacques Le Goff ${ }^{48}$, nos meios eclesiásticos medievais, desenvolveu-se um caloroso debate em torno do riso, a partir do questionamento se Cristo riu ou não durante a sua vida humana e da afirmação de Aristóteles de que o riso é próprio do homem. Se Jesus, o modelo a ser imitado pela humanidade, nunca riu, então o riso seria estranho ao homem cristão. Entretanto, em se considerando que o riso

48 Le GOFF, J. O riso na Idade Média. In: BREMMER, J.; ROODENBURG, H. (Org.). Uma história cultural do humor. Rio de Janeiro: Record, 2000. p. 69-70. 
é um traço distintivo do homem, aquele que ri estaria agindo mais de acordo com a sua própria natureza.

Alberti ${ }^{49}$ observa que o pensamento ocidental sobre o riso será orientado por essa dupla especificidade do homem, fundamentada no texto aristotélico e nos textos teológicos, ou seja, o riso é a prova da ambiguidade da condição do homem: ser, ao mesmo tempo, superior às coisas e aos animais e inferior ao transcendental e ao eterno. Tal ambiguidade é evocada por Charles Baudelaire ${ }^{50}$, em um ensaio de 1855:

O riso é satânico, é portanto profundamente humano. Representa no homem a consequência da ideia da sua própria superioridade; e, de fato, como o riso é profundamente humano, é essencialmente contraditório, ou seja, é ao mesmo tempo sinal de uma grandeza infinita e de uma miséria infinita, miséria infinita em relação ao Ser absoluto de quem possui a concepção, grandeza infinita em relação aos animais. É do choque perpétuo destes dois infinitos que se solta o riso.

Uma concepção do humano e do riso tão medieval em seus termos, vinda de um poeta do século XIX, é oportuna aqui para assinalar que o modo cronológico como as ideias estão sendo comentadas não implica que uma concepção posterior sobre o tema tenha eliminado a anterior, nem se tornado melhor ou mais sofisticada, ou seja, espera-se que não haja aqui preconceitos evolucionistas, positivistas, valorativos ou de qualquer outra natureza em relação às teorias.

Retomando, pois, a discussão e encaminhando-a para o século XVI, agora sob o ponto de vista de Bakhtin ${ }^{51}$, ele diz que:

A atitude do Renascimento em relação ao riso pode ser caracterizada, de maneira geral e preliminar, da seguinte maneira:

49 ALBERTI, 1999. p.69.

50 BAUDELAIRE, C. Da essência do riso. Almada: Íman edições, [19--]. p. 19.

51 BAKHTIN, M. A cultura popular na Idade Média e no Renascimento: o contexto de François Rabelais. São Paulo: HUCITEC,1987. p. 57-58. 
o riso tem um profundo valor de concepção do mundo, é uma das formas capitais pelas quais se exprime a verdade sobre $o$ mundo na sua totalidade, sobre a história, sobre o homem; é um ponto de vista particular e universal sobre o mundo, que percebe de forma diferente, embora não menos importante (talvez mais) do que o sério; por isso a grande literatura (que coloca por outro lado problemas universais) deve admiti-lo da mesma forma que ao sério: somente o riso, com efeito, pode ter acesso a certos aspectos extremamente importantes do mundo.

A atitude do século XVII e seguintes em relação ao riso pode ser caracterizada da seguinte maneira: o riso não pode ser uma forma universal de concepção do mundo; ele pode referir-se apenas a certos fenômenos parciais e parcialmente típicos da vida social, a fenômenos de caráter negativo; o que é essencial e importante não pode ser cômico; a história e os homens que a encarnam (reis, chefes de exército, heróis) não podem ser cômicos; o domínio do cômico é restrito e específico (vícios dos indivíduos e da sociedade); não se pode exprimir na linguagem do riso a verdade primordial sobre o mundo e o homem, apenas o tom sério é adequado; é por isso que na literatura se atribui ao riso um lugar entre os gêneros menores, que descrevem a vida de indivíduos isolados ou dos estratos mais baixos da sociedade; o riso é ou um divertimento ligeiro, ou uma espécie de castigo útil que a sociedade usa para os seres inferiores e corrompidos. De uma maneira um pouco esquemática, naturalmente, essa é a definição da atitude dos séculos XVII e XVIII em relação ao riso.

As reflexões de Bakhtin ${ }^{52}$ atribuem ao riso na Renascença uma forma de concepção de mundo tão importante (ou talvez mais do que) quanto o sério. Alberti questiona essa posição, argumentando que a capacidade do riso de apreender o mundo para além dos limites do pensamento sério, como almeja Bakhtin para o riso renascentista, só seria adquirida em épocas posteriores. Ela argumenta que a positividade do riso desse período é a "ausência de remorso", que

52 BAKHTIN, 1987. 
permite que se ria do torpe, da indecência, da deformidade; que se ria da conduta do outro, de sua burrice, do fato de se deixar enganar, o que de certa forma o aproxima daquilo que Bakhtin atribui ao risível do século XVII e XVIII ${ }^{53}$.

Tal "ausência de remorso" possibilita a modificação do sentido da noção de superioridade. Se antes, como queriam Platão e a teologia cristã, o homem superior era o que não ria, agora, graças à "licença para rir do outro", será permitido rir para castigar os costumes.

Esse será o argumento usado por Molière ${ }^{54}$ para solicitar junto ao rei a liberação de sua peça O Tartufo, proibida por quase cinco anos, por mostrar a Igreja de forma ridícula e depreciativa:

Se a finalidade da comédia é corrigir os vícios dos homens, não vejo por qual razão haveria privilegiados [...]. As melhores injunções de uma moral séria são menos poderosas, o mais das vezes, do que as da sátira; e nada corrige melhor a maioria dos homens do que a caricaturização dos seus defeitos. É atingir o vício em cheio o expô-lo à zombaria de todos. Não nos causa mossa o sermos criticados; mas não se tolera o escárnio. Queremos ser maus; mas não queremos ser ridículos.

Em torno desse mesmo raciocínio, o de que o homem teme o ridículo e que o riso castiga os costumes, Bergson ${ }^{55}$ constrói seu ensaio sobre a significação da comicidade, publicado em livro em 1900,

Pelo medo que inspira, o riso reprime as excentricidades, mantém constantemente vigilantes e em contato recíproco certas atividades de ordem acessória que correriam o risco de isolar-se e adormecer; flexibiliza enfim tudo o que pode restar de rigidez mecânica na superfície do corpo social [...]. Essa rigidez é a comicidade, e o riso é o seu castigo.

53 ALBERTI, 1999, p. 81-118.

54 MOLIÈRE. Prefácio. In: MOLIÉRE. O Tartufo ou o impostor. São Paulo: Martin Claret, 2003. p. 42.

55 BERGSON, 2001, p.15 
Para além de ser um divertimento superficial ou uma espécie de castigo útil usado para punir os seres inferiores, como querem Moliè$\mathrm{re}^{56}$ e Bergson ${ }^{57}$, o ponto mais relevante para a positivação do riso que se depreende dessa seção é a proposta de Bakhtin ${ }^{58}$, corroborada pela de Millôr ${ }^{59}$, de que o riso tem valor de concepção de mundo, capaz de exprimir a verdade sobre o homem em sua totalidade; é um modo de ver o mundo tão ou talvez mais esclarecedor do que o modo sério.

\section{A incongruência}

Como foi dito na seção anterior, a violação de uma regra - em termos de desmedida, impropriedade, aproximação de opostos, quebra de expectativa - é um dos elementos do cômico e, como tal, é o fulcro de uma série de análises sobre a questão do riso. Tais análises serão agora organizadas, a partir da palavra-chave incongruência, guardadas as devidas relativizações, com o auxílio, mais uma vez, de Verena Alberti ${ }^{60}$ em $\mathrm{O}$ riso e o risível na história do pensamento.

Do mesmo modo que os estudos do cômico com base na superioridade, as teorias que apontam para algum tipo de incongruência como causa do riso podem ser encontradas desde a Antiguidade.

Na Poética, Aristóteles diz que o emprego expressamente desmedido e fora de propósito de metáforas e outros nomes não habituais é um dos traços característicos da expressão cômica. No livro III da Retórica, ele menciona a troca de letras em uma palavra e a troca de palavras em um verso como recursos cômicos, salientando a necessidade de se manterem evidentes os dois sentidos da palavra, o usual e o resultante da mudança. Ao perceber que a palavra modificada pela troca de letra produz efeito diferente do esperado, Aristóteles está introduzindo, na reflexão sobre o riso, um outro recurso

\footnotetext{
56 MOLIÈRE, 2003.

57 BERGSON, 2001.

58 BAKHTIN, 1987.

59 FERNANDES, 2002.

60 ALBERTI, 1999.
} 
aliado à percepção da incongruência: o fator surpresa ou a quebra de expectativa ${ }^{61}$.

Ao se falar do pensamento ocidental medieval sobre o riso, na seção anterior, observou-se que ele seria orientado pela dupla especificidade da condição humana: ser, ao mesmo tempo, superior às coisas e aos animais e inferior ao transcendental e ao eterno. $O$ riso seria a prova da ambiguidade do homem ou, parafraseando Baudelai$\mathrm{re}^{62}$, seria o resultado do choque perpétuo entre uma grandeza infinita e uma miséria infinita, miséria infinita em relação a Deus, grandeza infinita em relação aos animais. Sendo que onde se lê "ambiguidade" e "choque" pode-se, agora, ler "incongruência".

Essa incongruência não diz respeito apenas a um recurso retórico para enfatizar o cômico na oratória ou na poesia, mas à percepção da peculiaridade da condição humana como sendo incongruente. Tal concepção ainda prevalece em estudos sobre o humor mais atuais, conforme as reflexões de Simon Critchley ${ }^{63}$, em On humor:

A incongruência do humor ressalta a excentricidade da situação humana em relação a si mesma e à natureza. O humor causa rachaduras no elo que une o ser humano a sua irrefletida existência cotidiana. No humor, assim como na ansiedade, o mundo torna-se estranho e desconhecido ao tato. Quando rio ou mesmo quando sorrio, eu me vejo como o estranho animal que sou e começo a refletir sobre o que antes eu considerava garantido.

Baudelaire, em 1855, e Critchley, em 2002, estão de acordo quanto à incongruência da condição do homem, mas diferem quanto à natureza daquilo que ocupa os pólos entre os quais o homem se encontra (se é que o lugar que ele ocupa é mesmo o meio). Para Baudelaire, o homem está entre Deus e os animais, logo o problema

61 ARISTÓTELES. Arte retórica e arte poética. 17. ed. Rio de Janeiro: Ediouro, 2005. p. 199 (Clássicos de Bolso).

62 BAUDELAIRE, [19--], p. 19.

63 CRITCHLEY, S. On humour. London: Routledge, 2002. p. 41. Tradução nossa. 
se coloca em termos de se ter um corpo e uma alma. Critchley ${ }^{64}$, por sua vez, pensa o problema em termos de se ter um corpo e se ser um corpo, o humor explora o conflito que existe entre os aspectos físicos e "metafísicos" de ser humano. O que faz rir, ele aposta, é o retorno do físico sobre o metafísico, quando a pretensa sublimação trágica do humano derrapa no cômico, o que talvez seja ainda mais trágico.

A novidade, nessa altura da exposição de teorias sobre o riso, não é o afastamento da noção de riso de superioridade, que de resto continuará, de alguma forma sempre presente, como, por exemplo, nas piadas racistas, machistas ou feministas. A modificação se dará na perspectiva de que o riso deixará de ser apenas um objeto a ser pensado e começará a integrar-se ao processo de pensar. O prazer do risível estará na possibilidade de alargar as ideias. O risível começará a inserir-se no domínio do entendimento como agente de seu alargamento. Se, antes, o desafio era compreender o riso como objeto passível de ser apreendido pelo entendimento, agora, trata-se de pensá-lo como vinculado à atividade de entendimento. Segundo Alberti65, contudo, essa mudança não é simples, porque, se, por um lado, o contraste cômico vai permitir o alargamento do conhecimento, por outro, no entanto, o risível vai continuar limitado à falsa verdade como a moda, os costumes, a superstição e a impostura. Continua prevalecendo a separação entre os objetos passíveis de serem ridicularizados e aqueles cuja perfeição absoluta impede o contraste ou o germe do ridículo: Deus, a religião, a verdade e a virtude.

As teorias mais representativas do século $\mathrm{XX}$, tomando como critério mais o seu conteúdo do que a cronologia, são as que fomentam a noção do riso como um modo de ampliar o pensamento, de alargar a visão de mundo:

É preciso que, de vez em quando, descansemos de nós próprios, olhando-nos de cima e de longe e, com o longínquo da arte, rir ou chorar de nós e por nós mesmos: é preciso descobrirmos o herói e também o louco que se dissimulam

64 CRITCHLEY, 2002, p. 43.

65 ALBERTI, 1999, p. 159-160. 
na nossa paixão do conhecimento; sejamos felizes, de vez em quando, com a nossa estupidez, para que possamos continuar felizes com a nossa sabedoria! E é precisamente porque, no fundo somos pesados e sérios, e antes pesos do que homens, que nada nos faz melhor do que o chapéu do bobo: temos necessidade dele perante nós próprios, precisamos de toda a arte exuberante, flutuante, dançante, trocista, infantil e venturosa, para não perder essa liberdade que nos coloca acima das coisas e que nosso ideal exige de nós. ${ }^{66}$

A contradição ou a incongruência humana que Baudelaire ${ }^{67}$ expunha em termos de um eterno embate entre uma grandeza infinita em relação aos animais e uma miséria infinita em relação a Deus, Nietzsche ${ }^{68}$ coloca em termos do herói e do tolo que habitam o homem; não se trata mais de um homem entre duas forças externas infinitamente maiores ou menores do que ele, mas de dois aspectos contraditórios do humano dentro do humano.

De Baudelaire a Nietzsche, assiste-se, a uma gradativa "despotencialização" dos protagonistas do drama humano, seja ele real ou representado, e à consequente "normalização", no sentido de nivelamento, da incongruência da condição humana, incongruência como fonte de riso, que é o que interessa aqui. Para Baudelaire ${ }^{69}$, o riso nascia do espetáculo oferecido pelo ente, quase sobre-humano, atormentado entre ser Deus ou fera. Em Nietzsche ${ }^{70}$, o ser humano traz em si o herói e o parvo e pode fazer uso da tolice para manter a sabedoria, pode rir de si mesmo para não perder a necessária liberdade sobre as coisas. Já em Beckett ${ }^{71}$, por exemplo, não parece que categorias como "herói" e "parvo" façam muito sentido. Não parece haver liberdade

66 NIETZSCHE, F. A gaia ciência. São Paulo: Martin Claret, 2006. p. 103, §107.

67 BAUDELAIRE, [19--].

68 NIETZSCHE, 2006.

69 BAUDELAIRE, [19--].

70 NIETZSCHE, 2006.

71 BERGSON, 2001, p.7-15. 
sobre as coisas, não é ao imitar coisas, bichos $^{72}$ ou plantas ${ }^{73}$ que o ser humano se torna ridículo, isto acontece exatamente quando ele tenta agir como um homem.

Desse ponto de vista, a normalização ou nivelamento da incongruência significa entender que não se está acima ou abaixo de nada, que qualquer ação que se faça, tola ou sábia, não vai mudar o "acaso de toda a existência"74, que talvez não haja mesmo "nada a fazer"75 e, talvez, apenas "a comédia nos convenha"76.

Essas ponderações, realmente lúgubres para um estudo de humor, estão longe de propor um fim niilista para a discussão da incongruência, muito longe disso, o que se quer depreender daí é uma crítica às razões sempre postas em jogo para justificar o riso - seja ela o castigo aos costumes ou a percepção sagaz das contradições intrínsecas do ser humano - e uma espécie de licença para o que Cleise Mendes ${ }^{77}$ defende como o "direito a rir da besteira", contra todas as exigências para que o riso seja sempre crítico, reflexivo ou nobre, pois se existe algo que desafia o pensamento, diz ela, não é o chiste ou a piada inteligente, é aquilo que fora dos limites momentâneos da gargalhada tem valor irrisório, que é, exatamente, "a besteira cômica".

O prazer de rir da besteira cômica, desafiando as prescrições do "bom-gosto e do bom-senso" para que a comédia seja séria e só faça rir em nome de alguma causa nobre, é defendido também por Freud ${ }^{78}$, em seu estudo sobre os chistes. Ele diz que o prazer no nonsense advém de se poder escapar das imposições da razão e da lógica. E em virtude de o processo educativo restringir, na criança e no jovem, todo uso da linguagem que não esteja de acordo com o

72 Cf. PROPP,1992., p. 66-72.

73 CRITCHLEY, 2002, p. 58-59.

74 ROSSET, C. Logique du pire. Paris: Presses Universitaires de France, 1993. p. 173.

75 BECKETT, S. Esperando godot. São Paulo: Abril Cultural, 1976. p. 9.

76 DÜRRENMATT, F. Apresentação da obra. In: DÜRRENMATT, F. A visita da velha senhora. São Paulo: Abril Cultural, 1976. p. X.

77 MENDES, 2001, p. 128-130.

78 FREUD, S. Os chistes e sua relação com o inconsciente. Rio de Janeiro: Imago, 1996. Rio de Janeiro: Imago, 1996a. (Edição standard brasileira das obras psicológicas completas, v. 8). 
pensamento lógico e a distinção entre verdadeiro e falso, a rebelião contra a compulsão da lógica e da realidade é profunda e duradoura.

O que vale ressaltar, em termos de positividade do humor, desses últimos autores citados é o afastamento das razões desqualificadoras e/ou punitivas do riso para dar lugar ao prazer de rir, que é o assunto da próxima seção.

\section{A catarse}

Já tendo considerado as questões da superioridade e da violação da regra (incongruência), a análise se volta agora para os aspectos da comicidade que, ao garantir ao espectador, ou ao leitor, uma distância segura do drama, fazem com que, em lugar da simpatia, ocorra a derrisão.

De maneira análoga ao que se deu com os outros dois aspectos tratados, os estudiosos do riso divergem quanto ao que ocorre entre a comédia e o seu público. Há os que são partidários de uma espécie de apatia crítica, acreditando que, na comédia, a plateia permanece indiferente, analítica, julgando friamente o comportamento desviante que merece ser ridicularizado. Outros negam essa indiferença racional perante o riso e creem que a comédia suscita emoções diferentes, mas tão intensas quanto o temor e a piedade da tragédia.

Entre os defensores do riso indiferente, destaca-se Bergson ${ }^{79} \mathrm{e}$ seu $O$ riso: ensaio sobre a significação da comicidade. O autor considera que um dos aspectos fundamentais para se entender o riso é que ele se faz acompanhar da insensibilidade, que a comicidade se produz na indiferença, tendo como maior inimigo a emoção. A comicidade dirige-se à inteligência pura e, para produzir o seu efeito máximo, ela exige algo como "uma anestesia momentânea do coração". E diz também que essa inteligência, para saborear o cômico que se lhe dirige, deve permanecer em contato com outras inteligências. $O$ isolamento

79 BERGSON, 2001, p. 2-5. 
torna insossa a comicidade. O riso precisa de eco, é algo que necessita do grupo para ser devidamente desfrutado.

Em oposição à formulação bergsoniana de que a indiferença é condição indispensável ao riso, encontra-se o trabalho de Cleise Mendes ${ }^{80}$, A gargalhada de Ulisses: um estudo da catarse na comédia. No resumo dessa obra, ela diz entender catarse como uma experiência estética, circunscrita e atualizada no espaço-tempo de um pacto lúdico proporcionado pelo drama, capaz de mobilizar ao mesmo tempo a inteligência e a emoção, e parte para estudá-la na comédia. Recusando o pré-requisito da "anestesia momentânea do coração" como necessário ao efeito cômico, a catarse cômica é entendida como uma forma de conhecimento capaz de ativar não apenas a apreensão lógico-racional, mas também o repertório de emoções, imagens, conceitos, afetos e valores do receptor. Sendo assim, o processo catártico deve ser compreendido dentro do espectro das paixões humanas, em seu estreito vínculo com os aspectos éticos e sociais nele implicados.

Entre os aspectos teóricos da comicidade que a autora discute, estão alguns dos pré-requisitos que Bergson propõe para o cômico: a insensibilidade e a cumplicidade. Sobre a primeira, que ela chama de "falácia da insensibilidade", ela argumenta que Bergson confundiu o distanciamento de determinadas emoções com a imagem de um espectador reduzido à pura inteligência. Ao afirmar que o riso exige o banimento de qualquer reação afetiva, ele está, na verdade, referindo-se a emoções bem determinadas: a piedade e o medo. O riso bergsoniano requer a exclusão de qualquer simpatia pela personagem, requer uma separação entre sensível e inteligível, entre mente e coração, implicando "[...] uma alternância inconciliável entre 'rir de' e 'sentir com' vistos como movimentos excludentes de afastamento e aproximação segundo a presença/ausência de identificação com a personagem"81.

Quanto à cumplicidade, ela acontece quando o espectador "indiferente" do cômico afasta-se do objeto risível e aproxima-se dos

80 MENDES, 2001, p.vii.

81 MENDES, 2001, p. 42-45. 
demais observadores, igualmente neutros, promovendo a comunhão de inteligências. Este movimento simultâneo de afastamento, pela derrisão, do que é estranho e de aproximação dos iguais reitera a utilidade e a significação social do riso. Quanto a esse aspecto, Mendes observa que, embora Bergson se refira aí ao contágio do riso no sentido da reunião concreta, física, de espectadores num mesmo local, essa ideia de cumplicidade pode ser aprofundada aplicando-a à situação do receptor isolado. Melhor do que dizer que as pessoas riem em grupo, seria reconhecer que aquilo que ri em cada pessoa quando ela ri - é o grupo, querendo dizer que o comediógrafo aposta numa certa comunhão de valores que estão circunscritos a um dado perímetro social, a uma "paróquia". Não significa, entretanto, que as pessoas tenham transformado-se provisoriamente em puras inteligências, mas justamente o contrário; esse tipo de riso, longe de ser um exercício crítico, é um riso "por contágio", cúmplice de conceitos e preconceitos grupais ${ }^{82}$.

Mendes ${ }^{83}$ adverte que o que Bergson denomina "a emoção" são apenas os afetos recomendados pela catarse aristotélica, piedade e terror; sua teoria, centrada no espectador insensível, não leva em consideração as emoções suscitadas pela comédia, mas apenas aquelas que ela deve evitar. Mas reconhece o fato de que o efeito cômico parece exigir que o espectador não se deixe imantar pelo drama da personagem e dele mantenha uma distância estratégica. Admitindo, provisoriamente, que Bergson tem razão em associar o efeito cômico ao bloqueio de certas e determinadas emoções, a autora ressalta que o distanciamento do espectador e a própria obra cômica são construídos conjuntamente. Isso se inicia desde o momento em que o comediógrafo, para conter ou minimizar sua própria simpatia para com a personagem-alvo do ridículo, escolhe um específico conjunto de traços para compô-la.

O que daí se pode concluir é que a boa receita de comédia deve incluir o passo de "isolar", em meio à alma da personagem, o sentimento que se lhe atribui e fazer dele "um estado parasita dotado de

82 Ibid.,loc.cit.

83 Ibid., p. 35-51. 
existência independente" ${ }^{84}$, para impedir a empatia do espectador. Ou seja, a etapa da "insensibilidade" bergsoniana é necessária para se obter a antítese das emoções da tragédia aristotélica. É preciso não se compadecer das personagens e não se aterrorizar diante das consequências de falhas que são, afinal, levianas, superficiais já que não acarretam morte ou perda considerável, apenas a punição do ridículo ${ }^{85}$.

Embora Mendes esteja de acordo com Bergson quanto a ser necessário afastar o terror e a piedade para se criar o contexto ótimo para a recepção da comédia, ela critica a noção de que a neutralização destes dois afetos específicos reduza o espectador à pura inteligência. Segundo ela, os autores de comédia, de Aristófanes ao besteirol, tanto quanto os das formas não-cômicas do teatro, jamais se dirigiram à pura inteligência, ao julgamento frio do espectador. A ideia de uma recepção puramente intelectual, sem interferência afetiva, é um mito racionalista, cujo objetivo é conferir uma suposta nobreza ética ao ato de se rir de alguém ${ }^{86}$.

O fato de, por séculos a fio, críticos e teóricos acreditarem na função social, ética e mesmo terapêutica da exposição aos vícios originou a noção de um circuito fictício de produção e recepção da comédia, tendo de um lado um comediógrafo plenamente consciente do corretivo cômico que aplicará às falhas de comportamento de sua paróquia, e, do outro, a plateia de intelectos rejubilando-se em vingar-se daqueles que se desviam das normas de convívio tão caras a todos. Esse modo de interpretar a relação entre o cômico e sua plateia, preconizando o isolamento da identificação e a consequente anulação da participação afetiva do espectador, reduz o fenômeno catártico a um processo puramente intelectivo. Tal ficção traduz o receio de enxergar as paixões em jogo na catarse cômica, pois uma coisa é rir, outra bem diversa é aceitar as razões por que se ri. Estas

84 BERGSON, 2001, p. 105.

85 MENDES, 2001., p. 53-54.

86 MENDES, op. cit, p. 60. 
podem assustar o observador, e ainda mais se ele tiver um alto conceito das motivações humanas e, principalmente, das suas próprias ${ }^{87}$.

O que não se quis ver nessas razões é que a insensibilidade em relação ao objeto não significa que a plateia seja uma observadora impassível, controlada pelo intelecto. Muito pelo contrário, é justamente por estar salvaguardada pelas estratégias do cômico e, consequentemente, não sofrer com a personagem, que ela pode dar livre curso a seus impulsos libidinais e agressivos. É possível supor a existência de um elemento sádico nesse jogo, no sentido de não se tratar apenas de bloquear a empatia, mas de deliciar-se com o sofrimento alheio, de obter prazer com a dor do escravo ou súdito do ritual orgíaco. É uma questão de se reduzirem os castigos físicos à exposição ao ridículo. E nem é preciso reduzir tanto assim, basta pensar em todas as surras, quedas e tombos que sofrem infalivelmente alguns personagens da comédia, das farsas populares e do humorismo televisivo, para o puro deleite do espectador. O que se pode concluir com isso é que o impedimento da piedade e do terror é pré-requisito para dar lugar a outro tipo de paixões. Se o gênero trágico explicita e ritualiza o luto e o sofrimento, o gênero cômico parece lançar mão de um alto grau de disfarce dos afetos em jogo ${ }^{88}$.

Não há dúvidas quanto à necessidade de isolamento das emoções tradicionalmente associadas ao efeito trágico para que o efeito cômico possa ocorrer. O equívoco está em confundir estas emoções - piedade e terror - com toda e qualquer participação afetiva do receptor da comédia. É necessário, pois, afastar a ideia sedimentada do espectador neutro, dotado de "inteligência pura", pois ela representa um empecilho ao reconhecimento do fenômeno catártico próprio da comédia. Melhor dizendo, ela representa uma barreira para a compreensão de qualquer obra de ficção, uma vez que nenhuma delas é partilhada ou coproduzida por intelectos puros, o que torna ainda mais curiosa a persistência da ideia de um espectador da comédia

87 MENDES, p. 61-62.

88 Ibid., p.62-63. 
superior e impassível, mesmo depois de ter recebido um golpe mortal de Freud em sua teoria sobre os chistes ${ }^{89}$.

Os chistes servem ao propósito inconsciente de satisfazer a um instinto - libidinoso ou hostil - perante um obstáculo, que pode ser uma norma social ou uma repressão psíquica; driblando essas barreiras, os chistes obtêm prazer de fontes que de outra forma seriam inacessíveis. Eles funcionariam, então, como um disfarce, através do qual se pode dar vazão, de modo socialmente aceito, a impulsos obscenos e hostis, que, sem a máscara, seriam repugnantes ou reprimidos ${ }^{90}$.

Aceitando-se os argumentos freudianos da ambiguidade constitutiva do efeito chistoso - a intenção consciente de fazer rir por uma razão inconsciente agressiva ou obscena -, é forçoso admitir a presença das emoções no processo cômico. O que se precisa é afastar emoções bem determinadas, talvez todas as que tenham relação com compaixão e medo, mas não as que estão associadas à hostilidade e à libido. Para reintroduzir a participação afetiva na catarse cômica e chegar à positividade das emoções suscitadas pela comédia, Mendes parte da ideia de que o terror e a piedade, na catarse trágica, não são emoções a serem somadas unidirecionalmente num mesmo vetor, mas sim afetos que se equilibram dialeticamente, permitindo ao mesmo tempo aproximação e distanciamento. É necessário, pois, que haja um equilíbrio das duas forças, uma distância ótima entre o cognoscente e o cognoscível, para que o acontecimento catártico ocorra. ${ }^{91}$

Buscando, em Aristóteles, os afetos compatíveis com o efeito cômico, Mendes salienta que, na Retórica, a paixão oposta ao medo ou temor é a confiança. Suas características são a distância, em relação ao que pode fazer mal, e a superioridade, em relação ao que, não pode fazer mal, porém o mais importante na comédia é a confiança que acontece justamente porque um dano ou perigo cresceu a ponto de ser temido para depois ser superado. Seria essa a função do suspense cômico, bem como das cenas de reconhecimento que trazem o alívio ao desfazer mal-entendidos, desacertos e incongruências.

89 MENDES, 2001. p. 65-66.

90 FREUD, 1996a. p. 100-102.

91 MENDES, op. cit., p. 67-72. 
Para os que subestimam um dano a ser infligido no universo cômico - crendo que ele não suscitaria efetivo temor, por não passar de um lance a mais no jogo da comédia -, bastaria imaginar um final diferente para certos enredos consagrados (como em O Mercador de Veneza, Tartufo e O Auto da Compadecida) e ver que esses perigos (respectivamente, dar a vida em pagamento de uma dívida; ser privado dos bens, da respeitabilidade e do amor da família e resignar-se a uma existência miserável, sob o arbítrio dos poderosos) são, na maioria das vezes, bastante dolorosos caso não se dissolvessem como um pesadelo graças à sorte, à providência ou, mais frequentemente, ao uso da astúcia ${ }^{92}$.

Quando se faz uso da astúcia contra alguma ameaça aterradora ou obstrutora, isto proporciona um sentimento de triunfo, algo como um grau superlativo de confiança e de autoconfiança, que se pode chamar de júbilo. Foi pela astúcia que Ulisses escapou de ser devorado pelo ciclope Polifemo, usando uma pele de carneiro e um jogo de palavras - "Meu nome é Ninguém" - e deu, o que parece ter sido, a primeira gargalhada da literatura ocidental. Esse riso de quem escapou à morte não pelo valor guerreiro, como Aquiles, mas sim pela burla engenhosa, fez surgir, desde Homero, um novo tipo de herói. Aquele que representa o talento humano de jogar com o que dispõe - uma brasa incandescente, um jogo de palavras - de garantir sua sobrevivência e seu prazer tirando proveito dos cochilos do, aparentemente sólido e invencível, dragão da realidade ${ }^{93}$.

Esse riso de triunfo sobre um dano iminente, associado ao sentimento de autoconfiança e superioridade que gera no espectador, que é característico da comicidade, parece ter sido compreendido e expresso com a clareza por Nietzsche:

Quando se considera que por centenas de milhares de anos o homem foi um animal extremamente sujeito ao temor, e que qualquer coisa repentina ou inesperada o fazia preparar-se para a luta, e talvez para a morte, e que mesmo depois, nas

92 MENDES, 2001, p.73-83.

93 Ibid., p. 84. 
relações sociais, toda a segurança repousava sobre o esperado, sobre o tradicional no pensar e no agir, então não deve nos surpreender que, diante de tudo do que seja repentino e inesperado em ação, quando sobrevém sem perigo ou dano, o homem se desafogue e passe ao oposto do temor: o ser encolhido e trêmulo de medo se ergue e se expande - o homem ri. ${ }^{94}$

Se o júbilo e a simpatia parecem ser facilmente perceptíveis no processo catártico da comédia, o mesmo não se dá com a inveja, que talvez seja menos reconhecível, por ser menos confessável. E, afinal, pergunta Mendes ${ }^{95}$, por que invejar uma personagem cômica? O que há de invejável nesse herói sem poder e sem força, que, ao expor seu ridículo, expõe o que há de finito, limitado e pequeno no humano? O que se pode cobiçar neste anti-herói que se acha mais sábio, mais forte, mais poderoso do que realmente é? Justamente a sua inconsciência. O que contribui para torná-lo ridículo - a ignorância de seu pedantismo, avareza, burrice etc - é o que vai transformá-lo numa criança aos olhos dos espectadores, livre para agir para fora e além dos limites de um padrão adulto de comportamento. Ao agir de modo louco e irresponsável, ao dizer bobagens e coisas absurdas, a personagem cômica parece manter intacto o patrimônio lúdico da infância, mencionado por Freud, e que o espectador sente ter perdido para a coerência e a seriedade das exigências sociais. De certa maneira, toda personagem cômica é uma criança grande, no sentido de acreditar e agir como se fosse maior, mais forte, mais bela, mais sábia do que realmente é. E a plateia, ao rir desse adulto pueril esperneando contra a realidade e agindo, ao mesmo tempo, de modo livre e ridículo, ao contrário do que Bergson ${ }^{96}$ afirma, não quer corrigi-lo ou curá-lo pelo riso, mas na verdade tem inveja dessa loucura e deseja frui-la através da comédia. Tal como na tragédia, a

94 NIETZSCHE, F. Humano, demasiado humano. São Paulo: Companhia das Letras, 2005. p. 119, §169.

95 MENDES, 2001.p.85-90.

96 BERGSON, 2001. 
personagem cômica parece funcionar como a vítima de um sacrifício ritual, amada e odiada, fonte de simpatia e júbilo tanto quanto alvo de pulsões erótico-agressivas.

Seja fruto das "afecções da alma", como quer Platão no Filebo, ou de "impulsos reprimidos", como quer Freud, as paixões desencadeadas pelo efeito cômico podem provir de tendências tão opostas permitindo o jogo estético-receptivo entre proximidade e distância, atração e repulsão - quanto provêm o terror e a piedade. Reconhecer a presença dessas paixões é o primeiro passo na investigação dos afetos próprios da catarse cômica. Dando continuidade à investigação de tais paixões e analisando os conceitos de alto e profundo, baixo e superficial, associados, tradicional e respectivamente, ao gênero trágico e cômico, Mendes ${ }^{97}$ defende o justo valor comédia tal como ela é e, relembrando o fato de que a avaliação crítica da comédia sempre esteve submetida a valores próprios da ótica de gêneros trágicos e sérios, ela afirma que a comédia não tem como se elevar ou se aprofundar para atingir algum tipo de validação estética, pois está não é sua via de ação. Pelo contrário, uma de suas características marcantes é trazer o lúdico à superfície, é explicitar constantemente seus meios e procedimentos, é denunciar propositalmente não apenas os disfarces da plateia, mas também as máscaras que o próprio dramaturgo utiliza para apontar estes disfarces. A comédia exibe-se integralmente como artefato, brinquedo, jogo; a técnica cômica baseia-se numa recusa de ocultação de qualquer significação profunda e misteriosa. Por isso pedir à comédia que seja profunda, é impor uma exigência que lhe é, como forma artística, estruturalmente estranha. Neste sentido, ela acrescenta:

Louvar o mérito de um comediógrafo exclusivamente pelo teor de tragicidade oculta em sua obra - procedimento usual na crítica de teatro e cinema - é algo assim como elogiar as plumas de um cão. Seria mesmo divertido parafrasear Aristóteles e transportar para o juízo da comédia sua afirmação

97 MENDES, 2001, p.107. 
dirigida à tragédia, ou seja, que 'dela não há que extrair toda a espécie de prazeres, mas tão só o que lhe é próprio'. ${ }^{98}$

No intuito de valorizar a comédia exclusivamente pelo que lhe é próprio, Mendes cita a obra de Mikhail Bakhtin, cujo mérito, primeiramente, está em, sobre as bases do realismo grotesco, restabelecer a legitimidade do rebaixamento como princípio artístico:

Degradar significa entrar em comunhão com a vida da parte inferior do corpo, a do ventre e dos órgãos genitais, e portanto com atos como o coito, a concepção, a gravidez, o parto, a absorção de alimentos e a satisfação das necessidades naturais. A degradação cava o túmulo corporal para dar lugar a um novo nascimento. E por isso não tem somente um valor destrutivo, negativo, mas também positivo, regenerador: é ambivalente, ao mesmo tempo negação e afirmação. Precipita-se não apenas para o baixo, para o nada, a destruição absoluta, mas também para o baixo produtivo, no qual se realizam a concepção e o renascimento, e onde tudo cresce profusamente. $O$ realismo grotesco não conhece outro baixo; o baixo é a terra que dá vida, e o seio corporal; o baixo é sempre o começo. ${ }^{99}$

Um segundo aspecto relevante na obra de Bakhtin ${ }^{100}$ é a percepção de que o riso grotesco sofre um empobrecimento a partir do século XVII, assinalando uma mudança de paradigma na avaliação da comicidade e do riso. Este que, da Comédia Antiga até o Renascimento, foi considerado como "dom de Deus" e privilégio do homem (Aristóteles), remédio do corpo e do espírito (Hipócrates) e principalmente como concepção de mundo, diferente da visão séria, mas não inferior a ela, terá, a partir do século XVII, o seu domínio limitado a abrigar os vícios dos seres inferiores e a ser visto como

98 MENDES, 2001, p.107.

99 BAKHTIN, 1987, p.19.

100 MENDES, 2001, p.111-112. 
algo ora frívolo ora diabólico, no máximo justificado como castigo útil aos desvios da norma social.

Entre os estudos críticos e teóricos que defendem o "bom-gosto" e propõem uma "evolução" do riso bárbaro até uma comédia elegante, é reiterada a ideia de que, quanto mais afastada do corpo, da terra, da materialidade, maior o valor artístico de uma comédia. Esta hierarquia se estabeleceu não apenas entre os limites do trágico e do cômico, como marca superior e inferior nos diferentes graus de excelência dos gêneros dramáticos, mas também no interior das próprias formas de comicidade. Nesse domínio, há uma gradação que vai do baixo cômico ao humor, que é valorizado por ser um modo de enunciação leve, agudo, sutil e inteligente ${ }^{101}$.

O humor, com o seu requintado jogo de palavras e de ideias, busca o riso inteligente e atrai todo o mérito crítico devido a sua idealidade, ou seja, a seu (suposto) afastamento das exigências do corpo, o que remete à observação de Bergson ${ }^{102}$ quanto ao cuidado dos tragediógrafos em neutralizar o corpo de suas personagens a ponto de os heróis de tragédia não beberem, não comerem, não se agasalharem e, se possível, nem se sentarem. Sentar-se no meio de uma fala seria lembrar que se tem um corpo, quando são os movimentos da alma que devem estar em evidência, e todo desvio de atenção para o peso da matéria corre o risco de infiltração cômica. Esse corpo diáfano, veículo quase incorpóreo de conteúdos morais, intelectuais e espirituais superiores, é a imagem dramatúrgica mais afastada da espessa corporalidade dos agentes cômicos. Compreende-se, portanto, a defesa que faz Bakhtin da vitalidade do baixo cômico popular e de sua desqualificação do humor em termos de uma espécie de riso reduzido ${ }^{103}$.

Já sob a perspectiva da ética da comédia, a concepção de mundo que tem sido perpassada, desde a Antiguidade, é que o ridículo parece estar exatamente na atitude de afastar-se do cotidiano, do terreno, dos aspectos concretos da existência, da vida no que tange

101 MENDES, op. cit, p. 141-142.

102 BERGSON, 2001, p. 39.

103 MENDES, 2001. p.142-143. 
às suas necessidades físicas e corporais. Faz, talvez com razão, da figura do sábio distraído, alheado da terra e do corpo, um alvo fácil do riso e um tipo costumeiro no painel da comédia ${ }^{104}$.

O modus operandi do cômico não abre mão da referência à materialidade, ao corpo, ao baixo. Porém o baixo é menos o que é representado (vícios, desvios, falhas, obscenidades etc.) do que um certo "ângulo de visão". O modo de ver do cômico, por olhar de baixo, desconfia de tudo que está no alto, de tudo que é excessivamente grave ou solene, e busca puxar para si tudo que caia no seu ângulo de visão. A ação cômica, portanto, não retrata o que é inferior na ética dos comportamentos ou na posição de poder das personagens, mas provoca um movimento irresistível que a tudo derruba, porque está sendo puxado para baixo pela força desse olhar desestabilizador ${ }^{105}$.

Para esse desejo de rebaixamento que excita o poder da comédia, Bakhtin ${ }^{106}$ sugere que "cansa olhar para cima, é necessário baixar os olhos. Quanto mais poderosa e duradoura for a dominação das coisas elevadas, maior satisfação provocam o seu destronamento e rebaixamento".

A degradação, que parece ser um traço consensual presente em diferentes teorias do cômico, foi um gesto constantemente investido de uma finalidade superior, educativa, moral, como uma forma de validar o perigoso poder desestabilizador do olhar cômico, contra o qual nada parece estar suficientemente a salvo. Contudo, é possível considerar que a força cômica, enquanto força, tem como impulso único exercer-se, manifestar-se, apropriar-se de um aspecto do real e dominá-lo segundo suas próprias leis, e para isso não cessou de colocar em ação, em cada época e lugar, renovadas formas dramáticas, sempre cambiáveis, sempre em mutação perante o desgaste decorrente do atrito com outras forças ${ }^{107}$.

104 MENDES, 2001, p. 143-145.

105 Ibid., p.147-150.

106 BAKHTIN, 1987, p. 266-267.

107 MENDES, op. cit., p. 150. 
O que Mendes ${ }^{108}$ buscou identificar na comédia e na sua catarse não foi a presença recorrente de determinados temas e técnicas, mas sim a existência de um método de representação que provoca um determinado tipo de recepção. Esse método consistiria em desconfiar sistematicamente de todas as verdades dadas como garantidas, valendo-se, para isso, da fantasia, do inverossímil, da negação da causalidade. Com isto, o que o cômico, assim como o jogo e a pornografia, se propõe é à diversão, opondo-se, assim, à conversão própria do trágico, do erotismo e do sagrado.

O modo cômico de responder ao mundo representa uma espécie de desvio de rota que remete à infância, que zomba das verdades absolutas, parodia os discursos sérios; representa uma fugaz fantasia de triunfo capaz de exorcizar fantasmas e preencher a falta e o desejo. Na catarse cômica, pode-se abandonar momentaneamente a verticalidade que a todos crucifica e paralisa no embate das falas autoritárias que descem contra as vozes ressentidas que se elevam. O cômico talvez seja uma saída, ainda que transitória, dessa trágica rede de acusações e ressentimentos ${ }^{109}$.

A busca de tantos fiadores para defender a positividade do modo humorístico de ver o mundo é necessária, porque ainda prevalece a ideologia de que a verdade e o saber são da ordem do sério ${ }^{110}$.

A última afirmação de Mendes aponta um caminho para fazer a ponte entre essas reflexões teóricas e a invisibilidade do humor escrito por mulheres no Brasil, quando ela diz que buscou identificar na comédia não a recorrência de temas e técnicas, mas a existência de um método de representação que põe em cheque verdades e garantias através da diversão, definindo assim o método do cômico.

A força de tal método consiste em desequilibrar as verdades tradicionalmente aceitas e, como disse Millôr, mostrar que o pé do santo é de barro e que o rei está nu. Para as mulheres, tomar tal

108 MENDES, 2001, p. 332-334.

109 Ibid., p. 332.

110 NEVES, L. F. B. A ideologia da seriedade e o paradoxo do coringa. In: NEVES, L. F. B. O paradoxo do coringa e o jogo do poder \& saber. Rio de Janeiro: Achiamé, 1979.p. 47-57. 
atitude significa quebrar as regras da posição passiva e subordinada, que lhes foi conferida por séculos.

No que tange ao humor escrito por mulheres, quando os compiladores não levam em consideração essa produção para suas antologias ou quando teóricos e colunistas vêm a público dizer que as mulheres não sabem reconhecer nem fazer humor, estão passando ao largo de sua capacidade de desconfiar e zombar das verdades, de parodiar os discursos sérios e, também, de se divertir com isso, como se verá nos capítulos seguintes. 